\title{
The effects of supplementing diets for weanling pigs with organic acids. A review
}

\author{
V.M. Gabert ${ }^{1}$ and W.C. Sauer \\ Department of Animal Science, University of Alberta \\ Edmonton, T6G-2P5, Canada
}

(Received 9 May 1994; accepted 12 May 1994)

\begin{abstract}
Supplementation of diets for weanling pigs with organic acids (e.g. citric, formic, fumaric and propionic acid) has been shown, in many cases, to increase average daily weight gain (ADG, range 4 to $27 \%$ ) and gain to feed ratio $(\mathrm{G} / \mathrm{F}$, range 3 to $15 \%)$ and reduce the incidence of diarrhea. However, organic acid supplementation may not always improve $A D G$ or $G / F$. Potential reasons for inconsistent results are briefly discussed. The growth promoting effects of organic acids may be attributed to increased nutrient and energy retention and digestibility (up to 4\%), alteration of bacterial populations and metabolites in the gastrointestinal tract and(or) an effect on metabolism. More research on the physiological, microbial and biochemical effects of supplementing diets for weanling pigs with organic acids is necessary to provide better understanding of their mode of action.
\end{abstract}

KEY WORDS: organic acid, pig, digestibility, microbiology, metabolism

\section{INTRODUCTION}

Pigs, weaned at 3 to 4 weeks of age, often exhibit low or no weight gain, low feed intake and often diarrhea. The period after weaning is often referred to as the "post-weaning check or lag period" and may persist for up to 2 weeks. As was reviewed by Kidder and Manners (1978), the secretion of gastric $\mathrm{HCl}$ is relatively low during the first 3 to 4 weeks of life and reaches a plateau by 8 to 10 weeks. The secretions of pancreatic lipase, amylase and trypsin follow the same pattern

${ }^{1}$ To whom the correspondence should be adressed 
(Kidder and Manners, 1978). Supplementing diets with antibiotics to prevent diarrhea after weaning may result in selection of resistant strains of pathogenic bacteria. Therefore, interest in "natural" feed additives, such as organic acids, has developed.

Kirchgessner and Roth (1988) concluded that the growth promoting effects of organic acids may be due to: increased nutrient digestibility, decreased $\mathrm{pH}$ in the diet (and likely gastric $\mathrm{pH}$ ) and decreased bacterial growth and improved pepsin activity and metabolic effects, especially with respect to energy utilization. Excellent reviews, including those by Kirchgessner and Roth (1982a, 1988), Easter (1988) and Ravindran and Kornegay (1993), have been presented previously. The effects of organic acid supplementation on animal performance, nutrient and energy retention and digestibility, compounds in the gastrointestinal tract (GIT) and microflora and metabolism are summarized in this review. This review discusses statistically significant $(P<0.05)$ findings concerning the supplementation of weanling pig diets with organic acids. When information is lacking, data from studies involving growing pigs and other species are used.

\section{Animal performance}

When diets for weanling pigs are supplemented with organic acids, average daily weight gain (ADG) may be increased by up to $26.9 \%$ or decreased by up to $15.1 \%$ (Table 1 ). The range is not as wide for gain to feed ratio $(\mathrm{G} / \mathrm{F})$ which may be increased by up to $15.4 \%$ or decreased by up to $5.9 \%$. Potential reasons for the highly variable results between studies and even in the same study may relate to differences in diet type and composition, age of the animals used, length of feeding period and health status of the animals. These factors are discussed in more detail in the following pages. The ranges of supplementation rates used for citric (CA), formic (FoA), fumaric (FA) and propionic (PA) acid were 0.5 to $3 \%$, 0.35 to $2.4 \%, 1$ to $4 \%$ and 0.3 to $3 \%$, respectively. The maximum improvements in $A D G$ and $\mathrm{G} / \mathrm{F}$ when diets were supplemented with these acids were 7.4 and $11.0 \%, 26.9$ and $8.6 \%, 13.8$ and $15.4 \%, 13.8$ and $7.8 \%$, respectively. Supplementing weanling pig diets with organic acids can improve growth rate, however experiments aimed at addressing the question of variable performance responses have yet to be done. Organic acid supplementation may also decrease the incidence of diarrhea (e.g. Kirchgessner and Roth, 1987a, 1990). Decreases of up to $72 \%$ were reported, however the data were not analyzed statistically and no estimate of variation was given. Much more work is needed with respect to diarrhea before a definitive statement can be made concerning the health benefits of organic acid supplementation. 
TABLE 1

The effect of organic acid supplementation on weanling pig performance

\begin{tabular}{|c|c|c|c|c|c|c|c|c|c|}
\hline Acid & $\%$ & $\mathrm{DT}^{2}$ & $\mathrm{BW}^{3}$ & $\mathrm{LP}^{4}$ & $\mathrm{ADG}^{5}$ & $\% \triangle^{7}$ & $\mathrm{G} / \mathrm{F}^{6}$ & $\% \triangle^{7}$ & $\operatorname{Ref}^{8}$ \\
\hline \multirow[t]{3}{*}{ Citric } & $\begin{array}{l}0.5 \\
1.0 \\
2.0\end{array}$ & $\begin{array}{c}\text { CSM } \\
", \\
"\end{array}$ & $\begin{array}{c}6.9 \\
" \\
"\end{array}$ & $\begin{array}{c}28 \\
" \\
"\end{array}$ & $\begin{array}{l}355 \\
362 \\
365\end{array}$ & $\begin{array}{l}-4.3 \\
-2.4 \\
-1.6\end{array}$ & $\begin{array}{l}0.70^{*} \\
0.70^{*} \\
0.70^{*}\end{array}$ & $\begin{array}{l}+4.5 \\
+4.5 \\
+4.5\end{array}$ & B \\
\hline & $\begin{array}{l}1.0 \\
2.0\end{array}$ & $\underset{\mu}{\mathrm{CPX}}$ & $\begin{array}{c}8.7 \\
"\end{array}$ & $\begin{array}{l}28 \\
" ״\end{array}$ & $\begin{array}{l}423 \\
437\end{array}$ & $\begin{array}{l}+3.9 \\
+7.4\end{array}$ & $\begin{array}{l}0.65^{*} \\
0.69^{*}\end{array}$ & $\begin{array}{r}+5.2 \\
+11.0\end{array}$ & D \\
\hline & $\begin{array}{l}1.5 \\
3.0\end{array}$ & $\underset{"}{\mathrm{CSM}}$ & $\begin{array}{l}6.9 \\
7.1\end{array}$ & 28 & $\begin{array}{l}282 \\
304\end{array}$ & $\begin{array}{l}-8.1 \\
-1.0\end{array}$ & $\begin{array}{l}0.49 \\
0.53\end{array}$ & $\begin{array}{l}-3.0 \\
+5.3\end{array}$ & $\mathrm{H}$ \\
\hline \multirow[t]{3}{*}{ Formic } & $\begin{array}{l}0.35 \\
1.2\end{array}$ & $\begin{array}{c}\text { CPX } \\
"\end{array}$ & $\begin{array}{c}9.1 \\
"\end{array}$ & $\begin{array}{l}35 \\
" ״\end{array}$ & $\begin{array}{c}349^{*} \\
312\end{array}$ & $\begin{array}{l}+26.9 \\
+13.5\end{array}$ & $\begin{array}{l}0.50 \\
0.48\end{array}$ & $\begin{array}{l}+8.6 \\
+4.3\end{array}$ & A \\
\hline & $\begin{array}{l}0.6 \\
1.2 \\
1.8 \\
2.4\end{array}$ & $\begin{array}{c}\text { CPX } \\
" " \\
" \\
"\end{array}$ & $\begin{array}{l}6.1 \\
" " \\
" \\
"\end{array}$ & $\begin{array}{l}41 \\
" \\
" \\
"\end{array}$ & $\begin{array}{c}463^{*} \\
468^{*} \\
401 \\
325^{*}\end{array}$ & $\begin{array}{r}+20.9 \\
+22.2 \\
+4.7 \\
-15.1\end{array}$ & $\begin{array}{l}0.68^{*} \\
0.70^{*} \\
0.65 \\
0.63\end{array}$ & $\begin{array}{c}+4.6 \\
+7.7 \\
0 \\
-3.1\end{array}$ & $\mathrm{C}$ \\
\hline & $\begin{array}{l}0.25 \\
1.2\end{array}$ & $\begin{array}{c}\text { CPX } \\
",\end{array}$ & $\begin{array}{l}6.8 \\
6.8\end{array}$ & $\begin{array}{l}21 \\
"\end{array}$ & $\begin{array}{c}367 \\
395^{*}\end{array}$ & $\begin{array}{r}+5.8 \\
+13.8\end{array}$ & $\begin{array}{l}0.79^{*} \\
0.81^{*}\end{array}$ & $\begin{array}{l}+2.6 \\
+5.2\end{array}$ & $\mathrm{G}$ \\
\hline \multirow[t]{3}{*}{ Fumaric } & $\begin{array}{l}1.0 \\
2.0\end{array}$ & $\begin{array}{c}\text { CPX } \\
\text { " }\end{array}$ & $\begin{array}{c}8.7 \\
",\end{array}$ & $\begin{array}{l}28 \\
"\end{array}$ & $\begin{array}{l}431 \\
426\end{array}$ & $\begin{array}{l}+5.9 \\
+4.7\end{array}$ & $\begin{array}{l}0.66^{*} \\
0.67^{*}\end{array}$ & $\begin{array}{l}+5.9 \\
+8.1\end{array}$ & $\mathrm{D}$ \\
\hline & $\begin{array}{l}1.0 \\
2.0 \\
3.0 \\
4.0\end{array}$ & $\begin{array}{c}\text { CSM } \\
\text { ", } \\
", \\
",\end{array}$ & $\begin{array}{c}8.6 \\
, " \\
" \\
"\end{array}$ & $\begin{array}{l}28 \\
" \\
" \\
"\end{array}$ & $\begin{array}{l}261 \\
257 \\
296 \\
297\end{array}$ & $\begin{array}{c}0^{9} \\
-1.5 \\
+13.4^{*} \\
+13.8^{*}\end{array}$ & $\begin{array}{l}0.54 \\
0.57 \\
0.60 \\
0.60\end{array}$ & $\begin{array}{r}+3.8^{n} \\
+9.6 \\
+15.4 \\
+15.4\end{array}$ & $\mathrm{E}$ \\
\hline & $\begin{array}{l}1.5 \\
3.0\end{array}$ & $\begin{array}{c}\text { CSM } \\
, "\end{array}$ & $\begin{array}{l}7.1 \\
7.2\end{array}$ & $\begin{array}{l}28 \\
",\end{array}$ & $\begin{array}{l}244 \\
216\end{array}$ & $\begin{array}{r}-0.4 \\
-11.8\end{array}$ & $\begin{array}{l}0.55 \\
0.52\end{array}$ & $\begin{array}{l}-0.4 \\
-5.9\end{array}$ & $\mathrm{H}$ \\
\hline \multirow[t]{3}{*}{ Propionic } & $\begin{array}{l}0.3^{10} \\
1.0\end{array}$ & $\begin{array}{c}\text { CPX } \\
",\end{array}$ & $\begin{array}{c}9.1 \\
" \prime\end{array}$ & $\begin{array}{l}35 \\
" "\end{array}$ & $\begin{array}{l}246 \\
313\end{array}$ & $\begin{array}{r}-10.5 \\
+13.8\end{array}$ & $\begin{array}{l}0.46 \\
0.49\end{array}$ & $\begin{array}{c}0 \\
+6.5\end{array}$ & A \\
\hline & 2.0 & $\mathrm{CSM}$ & 7.5 & 28 & 241 & -4.4 & $0.55^{*}$ & +7.8 & $\mathbf{E}$ \\
\hline & $\begin{array}{l}1.0^{10} \\
2.0 \\
3.0\end{array}$ & $\begin{array}{c}\text { CSM } \\
", \\
"\end{array}$ & $\begin{array}{c}5.6 \\
" \\
"\end{array}$ & $\begin{array}{l}43 \\
" "\end{array}$ & $\begin{array}{l}388 \\
385 \\
395\end{array}$ & $\begin{array}{l}-3.2 \\
-4.0 \\
-1.5\end{array}$ & $\begin{array}{l}0.56 \\
0.56 \\
0.57\end{array}$ & $\begin{array}{c}-1.8 \\
-1.8 \\
0\end{array}$ & $\mathbf{F}$ \\
\hline
\end{tabular}

${ }^{1}$ Inclusion level of acid in the diet, \%

${ }^{2}$ Diet type: CSM-corn soybean meal; CPX-complex with many ingredients

${ }^{3}$ Initial body weight, $\mathrm{kg}$

${ }^{4}$ Length of experimental period, days

${ }^{5} \wedge$ verage daily weight gain, $g / d$

${ }^{6}$ Gain to feed ratio, g/g

${ }^{7}$ Percentage increase/decrease in ADG or G/F relative to control

${ }^{8}$ References: A - Bolduan et al., 1988; B - Broz and Schulze, 1987; C - Eckel et al., 1992;

$\mathrm{D}-$ Falkowski and Aherne, 1984; E- Giesting and Easter, 1985; F-Kirchgessner and Roth, 1982b;

G - Kirchgessner and Roth, 1987b; H - Radecki et al., 1988

${ }^{9}$ Linear effect of fumaric acid level, $\mathrm{P}<0.05$

${ }^{10}$ Luprosil-NC, BASF Corporation, Chemicals Division, Parsippany, NJ.

*Significantly different, $\mathrm{P}<0.05$ from control 
TABLE 2

The effect of organic acid supplementation of diets for weanling pigs on the apparent ileal and faecal digestibilities of dry matter, organic matter, crude protein and gross energy

\begin{tabular}{|c|c|c|c|c|c|c|c|c|c|}
\hline Acid & $\%^{1}$ & $1 / F^{2}$ & $\mathrm{DM} / \mathrm{OM}^{3}$ & $\% \Delta^{6}$ & $\mathrm{CP}^{4}$ & $\% \Delta^{6}$ & $\mathbf{G E}^{5}$ & $\% \triangle^{6}$ & Ref \\
\hline \multirow[t]{5}{*}{ Citric } & 0.5 & Face & $83.8^{*}$ & +1.1 & 81.8 & +1.0 & $82.1^{*}$ & +1.4 & B \\
\hline & 1.0 & $"$ & $84.7^{*}$ & +2.2 & 82.4 & +1.7 & $83.0^{*}$ & +2.5 & \\
\hline & 2.0 & $"$ & $83.7^{*}$ & +1.0 & 80.2 & -0.0 & 81.6 & +0.7 & \\
\hline & 1.0 & Faec & 80.2 & -0.7 & 78.6 & +0.3 & - & - & D \\
\hline & 2.0 & $"$ & 80.9 & +0.1 & 79.4 & +1.3 & - & - & \\
\hline \multirow[t]{8}{*}{ Formic } & 0.35 & Ile & 77.0 & +0.8 & 80.2 & 0 & - & - & $\mathbf{A}$ \\
\hline & 0.35 & Faec & 90.1 & -1.6 & 90.6 & -2.3 & - & - & \\
\hline & 0.6 & Faec & 89.2 & +0.9 & $88.4^{*}$ & +2.6 & 89.3 & +1.0 & $\mathrm{C}$ \\
\hline & 1.2 & $"$ & 89.6 & +1.4 & $89.1^{*}$ & +3.4 & 89.8 & +1.6 & \\
\hline & 1.8 & $"$ & 89.7 & +1.5 & $90.0^{*}$ & +4.4 & $90.3^{*}$ & +2.1 & \\
\hline & 2.4 & $"$ & 89.7 & +1.5 & $90.0^{*}$ & +4.4 & $90.6^{*}$ & +2.5 & \\
\hline & 1.0 & Ile & $87.8^{*}$ & -3.4 & 77.8 & -2.1 & - & - & $\mathrm{E}$ \\
\hline & 1.0 & Faec & $91.6^{*}$ & -2.9 & 86.9 & -1.8 & 90.1 & -3.0 & \\
\hline \multirow[t]{9}{*}{ Furamic } & 1.0 & Faec & 80.6 & -0.2 & 78.9 & +0.6 & - & - & D \\
\hline & 2.0 & $"$ & 80.9 & +0.1 & 79.8 & +1.8 & - & - & \\
\hline & 1.5 & Ile & 69.7 & -2.4 & 79.9 & -0.5 & - & - & $\mathrm{E}$ \\
\hline & 3.0 & Ile & 67.6 & -5.3 & $76.2^{*}$ & -5.1 & - & - & \\
\hline & 1.5 & Faec & 87.4 & -0.1 & 89.0 & -0.2 & 86.4 & -0.2 & \\
\hline & 3.0 & Faec & 87.1 & -0.5 & 88.4 & -0.9 & 85.7 & -1.0 & \\
\hline & 2.0 & Ile & 69.4 & +0.9 & 70.5 & +4.1 & - & - & $\mathrm{F}$ \\
\hline & 1.0 & Faec & $86.7^{*}$ & +1.3 & 87.3 & +2.5 & $87.2^{*}$ & +1.5 & $\mathrm{G}$ \\
\hline & 2.0 & $"$ & $87.3^{*}$ & +2.0 & $87.7^{*}$ & +2.9 & $87.7^{*}$ & +2.1 & \\
\hline \multirow[t]{4}{*}{ Propionic $^{8}$} & 0.3 & Ile & 75.5 & -1.2 & 76.8 & -4.2 & - & - & A \\
\hline & 0.3 & Faec & 88.6 & -3.3 & 90.9 & -1.9 & - & - & \\
\hline & 1.0 & Faec & 81.3 & +0.1 & 83.2 & +0.2 & 81.4 & -0.1 & $\mathrm{H}$ \\
\hline & 2.0 & Faec & 82.2 & +1.2 & 83.5 & +0.6 & 82.2 & +0.9 & \\
\hline
\end{tabular}

${ }^{1}$ Inclusion level of acid in the diet, \%

${ }^{2}$ Apparent ileal or faecal digestibility

${ }^{3}$ Dry matter or organic matter digestibility

${ }^{4}$ Crude protein digestibility

${ }^{5}$ Gross energy digestibility

${ }^{6}$ Percentage increase/decrease in DM, OM, CP or GE digestibility relative to control

${ }^{7}$ References: A - Bolduan et al., 1988; B - Broz and Schulze, 1987; C - Eckel et al., 1992; D-Falkowski and Aherne, 1984; E- Gabert, 1994; F- Giesting and Easter, 1991; G - Kirchgessner and Roth, 1980; H - Kirchgessner and Roth, 1982b

${ }^{8}$ Luprosil- NC, BASF Corporation, Chemicals Division, Parsippany, NJ

*Significantly different $(\mathrm{P}<0.05)$ from control

$(-)$ Not determined 


\section{Nutrient and energy retention and digestibility}

\section{Citric acid}

There is little information available in the literature concerning the effect of CA supplementation on nutrient and energy retention and digestibility. Falkowski and Aherne (1984) reported that supplementation with CA did not affect the apparent faecal digestibilities of crude protein (CP) and dry matter (DM) (Table 2). Broz and Schulze (1987) reported similar results. However, the apparent faecal digestibilities of organic matter (OM) and gross energy (GE) were increased by up to 2.2 and $2.5 \%$, respectively. More information is needed on the effect of CA supplementation. Sofar, no studies have investigated the effect of CA supplementation on the apparent ileal digestibilities of nutrients. As reviewed by Sauer and Ozimek (1986), the ileal rather than the faecal analysis method should be used especially with respect to protein (amino acid) digestibility.

\section{Formic acid}

In contrast to CA, the effect of FoA on nutrient and energy retention and digestibility has been investigated by many workers. Bolduan et al. (1988) reported no effect of FoA supplementation on $\mathrm{N}$-retention and $\mathrm{OM}$ and $\mathrm{CP}$ (both ileal and faecal) digestibilities (Table 2). However, Eckel et al. (1992) reported that FoA supplementation increased the apparent faecal digestibilities of CP and GE by up to 4.4 and $2.5 \%$, respectively (Table 2). Similar results were observed by Eidelsburger et al. (1992a). Formic acid supplementation in the previously mentioned studies may have improved protein digestion by reducing gastric $\mathrm{pH}$, however the effects on other nutrients are difficult to explain and may relate to an indirect effect of FoA via the microflora in the GIT. One study has investigated the effects of FoA supplementation on apparent ileal digestiblities. Gabert (1994) did not observe a positive effect of supplementing diets with $1 \%$ FoA on the apparent ileal digestibilities of amino acids (AA), DM, OM, CP and ash (Table 2). The lack of response may have been due to the highly digestible nature of the diet. In this study, the buffering capacity of two of the diets was increased by increasing the levels of $\mathrm{CaCO}_{3}$ and $\mathrm{CaHPO}_{4}$. There was no effect of increasing the buffering capacity on the apparent digestibilities of nutrients and energy. The growth promoting effects of organic acids may be influenced by the buffering capacity of the diet (Ravindran and Kornegay, 1993). The detrimental effects of feeding weanling pigs diets with high buffering capacity were discussed by Manners (1970) and Ravindran and Kornegay (1993). However, more investigation is needed to assess the importance of buffering capacity of the diet specially with respect to gastric and pancreatic secretions. 


\section{Fumaric acid}

As for FoA, the effects of FA supplementation on nutrient and energy retention and digestibility have been studied by several workers. Falkowski and Aherne (1984) and Eidelsburger et al. (1992b) observed that the apparent faecal digestibilities of CP and DM were not affected by FA supplementation (Table 2). However, other studies have shown that FA supplementation increased the apparent faecal digestibilities of $\mathrm{OM}$, ether extract, crude fibre, $\mathrm{CP}$, and $\mathrm{N}$-free extract (Kirchgessner and Roth, 1980; Kirchgessner et al., 1982; Pallauf et al., 1987). Radecki et al. (1988) reported that supplementation of FA did not affect digestible energy, metabolizable energy (ME), N corrected ME, $\mathrm{N}$ balance, percent $\mathrm{N}$ retained, apparent faecal $\mathrm{N}$ digestibility, $\mathrm{Ca}^{2+}$ balance, percent $\mathrm{Ca}^{2+}$ retained and $P$ balance and retention. However, Kirchgessner and Roth (1980) reported that FA supplementation increased the apparent faecal digestibilities of $\mathrm{Ca}^{2+}$ and $\mathbf{P}$ as well as $\mathrm{Ca}^{2+}$ and $P$ retention. A definitive statement on the effect of FA supplementation cannot yet be made until reasons for variable responses in digestibility and nutrient retention are investigated. However, Giesting and Easter (1991) and Gabert (1994) reported that supplementation with FA did not affect the apparent ileal digestibilities of DM, N and AA (Table 2). This is strong evidence that FA supplementation does not increase protein digestion as determined with the ileal analysis method.

\section{Propionic acid}

As for CA, there is little information on the effect of PA supplementation on nutrient and energy retention and digestibility. Kirchgessner and Roth (1982b) reported that supplementation with PA had no effect on the apparent faecal digestibilities of DM, $\mathrm{N}$ or GE (Table 2). Bolduan et al. (1988) did not observe an effect of PA supplementation on the apparent ileal and faecal digestibilities of OM and CP (Table 2). Mosenthin et al. (1992) found similar results in growing pigs; $2 \%$ PA supplementation did not affect the apparent ileal digestibilities of DM, OM, CP or ash. However, supplementation increased the apparent ileal digestibilities of some of the AA. As for CA and FA a definitive statement on the effect of PA supplementation cannot be made.

\section{Compounds in the GIT and microflora}

\section{Citric acid}

There is limited information in the literature on the effect of CA supplementation on compounds in the GIT and microflora. Risley et al. (1991) reported 
that CA supplementation had no effect on $\mathrm{pH}$ of the GIT contents, $\mathrm{Cl}^{-}$, volatile fatty acid (VFA), and non-VFA concentrations in the GIT. Similar results were reported by Risley et al. (1992). In addition, CA supplementation did not affect the number of total anaerobes, Lactobacillus, Clostridia, or Escherichia coli in the GIT. It appears, from these limited data, that CA supplementation has no effect on the microflora in the GIT.

\section{Formic acid}

In contrast to $\mathrm{CA}, \mathrm{FoA}$ supplementation decreased the $\mathrm{pH}$ of stomach contents (3.8 vs 4.0) (Bolduan et al., 1988). This is the only study that has demonstrated a decrease in $\mathrm{pH}$ in the stomach. However the method of $\mathrm{pH}$ measurement is critical and simply mixing the gastric contents and taking a sample of gastric digesta will only give an average value (F.X. Roth, personal communication). An alternative method would be to slaughter the animals, freeze the stomach in liquid $\mathrm{N}_{2}$, remove core samples from several areas and measure the $\mathrm{pH}$ once the samples have thawed (F.X. Roth, personal communication). In addition, Bolduan et al. (1988) reported that no E. coli were detected in the stomach of pigs fed diets supplemented with FoA and histological examinations of the stomach did not reveal any ulceration (Bolduan et al., 1988). The level of lactic acid in the stomach was decreased by FoA supplementation. However, there was no effect of FoA supplementation on total VFA or ammonia concentrations in the stomach or on lactic acid or ammonia concentrations or $\mathrm{pH}$ in the small intestine (Bolduan et al., 1988). Therefore, it appears that the secretion of $\mathrm{HCO}_{3}$ - from the pancreas overcame the additional acid load from the diet. Roth et al. (1992) and Gabert (1994) reported that supplementation of diets with FoA did not affect the VFA concentrations in the stomach or small intestine and the composition of the microflora in the ileum, caecum and colon. However, supplementation with FoA decreased the number of bacteria in the duodenum and jejunum. There is some evidence in the literature that FoA supplementation decreases microbial growth in the stomach and small intestine and this may be beneficial to the weanling pig.

\section{Fumaric acid}

Risley et al. (1991) reported that FA supplementation increased the concentration of fumarate in the stomach (444.2 vs $2.5 \mathrm{meq} / \mathrm{dL})$ and jejunum (93.6 vs $0.0 \mathrm{meq} / \mathrm{dL}$ ). However, supplementation with FA had no effect on the $\mathrm{pH}$ of the GIT contents, $\mathrm{Cl}^{-}, \mathrm{VFA}$ and non-VFA concentrations. The additional fumarate may have been absorbed or metabolized by microbes in the ileum, caecum and large intestine. Similar results were observed by Risley et al. (1992) 
and Gabert (1994). In addition, there was no effect of FA supplementation on the number of total anaerobes, Lactobacillus, Clostridia, or E. coli in the GIT. However, Sutton et al. (1991) reported that supplementation with FA decreased the number of $E$. coli in the stomach (3.87 vs $\left.4.46 \log _{10} / \mathrm{gram}\right)$ and increased acetate ( 68.3 vs $52.3 \mathrm{mM}$ ), propionate ( 60.9 vs $36.3 \mathrm{mM}$ ) and total VFA (166.3 vs $123.6 \mathrm{mM}$ ) concentrations in the caecum. Gedek et al. (1992) observed a decrease in the numbers of several groups of enteric bacteria in the duodenum, jejunum and ileum when diets were supplemented with FA. As for FoA, there is some evidence in the literature that FA supplementation decreases bacterial growth in the GIT and this may be beneficial to the weanling pig.

\section{Propionic acid}

Propionic acid supplementation may also have inconstant effects on the microflora of the GIT. Bolduan et al. (1988) did not detect any E. coli in the stomach of pigs fed diets supplemented with $1 \%$ PA. However, Sutton et al. (1991) did not observe an effect of supplementation with PA on Lactobacillus or $E$. coli in the GIT or VFA concentrations in the stomach, duodenum and caecum. However, supplementation with PA decreased the acetate and total VFA concentrations in the colon. Similar results were found by Mathew et al. (1991). However, pigs fed diets supplemented with PA had a higher number of Lactobacillus in the stomach and duodenum. The beneficial effects of Lactobacillus include protection against pathogen colonization (Muralidhara et al., 1977) and decreased incidence of diarrhea (Luckey, 1984). Mosenthin et al. (1992) reported that supplementation with PA decreased the concentration of cadaverine in caecal digesta of growing pigs. However, this may not be of importance. Porter and Kenworthy (1969) concluded that the overall production of diamines, primarily cadaverine and putrescine, is not an indication of predisposition to diarrhea. They reported that the microflora of normal and scouring animals may produce similar levels of cadaverine and putrescine.

\section{Metabolic effects}

\section{Acetic acid}

One of the metabolic effects of organic acid supplementation of weanling pig diets may be an N (AA)-sparing effect. Imoto and Namioka (1983) fed acetate to growing pigs, in the form of triacetin, at a rate of 5 and $10 \%$ of $\mathrm{ME}$ intake. Weight gain and $\mathrm{N}$-retention showed a linear relationship with increasing levels of acetate. The effect on weight gain was $0.09 \mathrm{~g}$ of gain $/ \mathrm{g}$ of acetate and the 
average $\mathrm{N}$-sparing effect was $32.9 \mathrm{mg} \mathrm{N} / \mathrm{g}$ of acetate. A linear increase in RNA, protein content and organ weight was observed in the liver, heart and femoral muscle. However, the total DNA content did not change in these tissues, indicating that acetate had no effect on the number of nuclei in the cells. However, under practical conditions supplementation of diets with acetic acid has not resulted in increased ADG or G/F (Zhang et al., 1986; Roth and Kirchgessner, 1988). An N-sparing effect has not been demonstrated with other organic acids.

\section{Citric acid}

The absorption of citrate has been studied; citrate and fumarate uptake from the intestinal lumen has been investigated using brush border membrane vesicles (BBMV) prepared from the proximal jejunum of calves (Wolffram et al., 1990) and pigs (Wolffram et al., 1992). The uptake of citrate and fumarate by BBMV occurs by a common $\mathrm{Na}^{+}$-gradient dependent mechanism that appears to be specific for tri- and dicarboxylates (Wolffram et al., 1990, 1992). However, citrate supplementation does not affect plasma chemical parameters, for example the concentrations of plasma inorganic $\mathrm{P}, \mathrm{Fe}^{2+}$, glucose, urea, total lipid, blood haemoglobin as well as Fe-binding capacity and transferrin saturation (Falkowski and Aherne, 1984; Grassman and Klasna, 1986; Broz and Schulze, 1987).

The effects of supplementation of diets with CA on intermediary metabolism in the rat liver have been investigated by Grassman and Kirchgessner (1979) and Grassman and Klasna (1986). There was no effect of CA supplementation on the activities of enzymes in the citric acid cycle. However, succinate dehydrogenase activity was increased in one study and decreased in another. Grassman and Kirchgessner (1979) reported that CA supplementation did not affect the activities of liver transaminases. However, Grassman and Klasna (1986) reported that CA supplementation increased liver glutamate dehydrogenase, glutamate oxaloacetate transaminase and glutamate pyruvate transaminase activities. An increase in transaminase activities may indicate that the carbon skeleton of citrate is being used to synthesize nonessential AA.

\section{Formic acid}

The metabolic effects of supplementing diets with FoA have been investigated by Grassmann et al. (1992). Formic acid supplementation increased the concentration FoA and urea in serum and increased the activities of $\alpha$-ketoglutarate dehydrogenase and glutamate pyruvate transaminase. The authors hypothesized that the increased urea concentration and increased 
enzyme activities were due to acidosis when diets were supplemented with 1.8 and $2.4 \%$ FoA. This is the only study that has investigated the metabolic effect of FoA supplementation.

\section{Fumaric acid}

Similarly to CA, supplementation with FA does not affect plasma chemical parameters. In a study with rats, Grassman and Klasna (1986) found that FA supplementation did not affect blood glucose, total lipid or urea concentrations. Eidelsburger et al. (1992c) reported no effect of FA supplementation on acid-base status. Falkowski and Aherne (1984) reported no effect of FA supplementation on plasma urea concentration. As previously discussed, fumarate is also actively absorbed from the jejunum.

The effects of supplementation of diets with FA on intermediary metabolism in the rat liver have been investigated by Tschiershwitz et al. (1982) and Grassman and Klasna (1986). There was no effect of FA supplementation on the activities of enzymes in the citric acid cycle. However, Tschiershwitz et al. (1982) reported that FA supplementation increased succinate dehydrogenase activity. Grassman and Klasna (1986) reported that fumarase activity in the cytosolic fraction was increased by FA supplementation. Fumaric acid supplementation increased liver transaminase (glutamate dehydrogenase, glutamate oxaloacetate transaminase and glutamate pyruvate transaminase) activities. As discussed under CA, this may indicate increased synthesis of nonessential AA.

\section{Propionic acid}

The metabolic effects of supplementing diets for weanling pigs with PA have not been investigated. However, similar effects as reported for CA and FA would be expected since PA is also metabolized via the citric acid cycle once it has been converted to succinyl-CoA (Voet and Voet, 1990). Propionate is likely absorbed from the intestine via passive diffusion (Bugaut, 1987).

\section{DISCUSSION}

The growth response of weanling pigs to organic acid supplementation depends on the type of diet (corn-soya bean meal vs corn-soya bean meal and whey, Burnell et al., 1988), level of acid (Giesting and Easter, 1985), type of acid (Edmonds et al., 1985; Radecki et al., 1988) and duration of feeding period (Kirchgessner and Roth, 1987b, 1990). Supplementation of weanling pig diets with organic acids has not consistently led to improved nutrient and energy 
retention and digestibility (Table 2). One consideration is the supply of digestible or available nutrients and energy from the diet. If it is adequate for the genetic potential of the animal, a response may not be observed. Another consideration is the time of sample collection relative to weaning. The growth promoting effects of organic acids are usually most predominant within two weeks of weaning (e.g. Radecki et al., 1988; Giesting et al., 1991). When there are positive effects, they are quite wide ranging and do not primarily concern protein. This may indicate, especially with respect to energy and fibre, that there is an indirect effect of acid supplementation via and effect on the microflora in the GIT. Also there is some evidence for a positive effect on mineral absorption likely via chelation.

The effects of organic acid supplementation on compounds in the GIT and microflora are inconsistent. One consideration is that samples for bacteriology are often taken at the conclusion of a growth trial (e.g. Sutton et al., 1991). By this time the digestive system of the weanling piglet may be fully developed. Another consideration is the importance of bacteria attached to the mucosa of the stomach and small intestine, as reviewed by Savage (1977) and Conway (1989). Unless isolations of bacteria from the mucosa are done, attached bacteria cannot be enumerated by simply taking a digesta sample. The time of digesta sampling relative to feeding and the disease status of the animals in the study must be taken into consideration.

The metabolic effects of supplementing diets with citric and fumaric acid have been the most extensively investigated. However, most studies have been done with rats. The relationship between protein metabolism and supplementation with organic acids has only been investigated with acetate by Imoto and Namioka (1983). Transport studies have been performed in vitro (Wolffram et al., 1990, 1992). These investigations have implications for the elucidation of the modes of action of citric and fumaric acid. The contribution of citric and fumaric acid to the formation of ATP and possibly a subsequent $\mathrm{N}$-sparing effect on glucogenic AA, such as glutamine, could facilitate the rapid developmental changes that are taking place in the digestive tract. However in vivo studies have yet to be conducted to quantify the importance of citrate, fumarate and propionate absorption.

\section{CONCLUSIONS}

The supplementation of diets for weanling pigs with organic acids may improve growth performance. This may be due to increased nutrient and energy retention and digestibility, alteration of bacteria in the GIT, bacterial metabolites and other compounds in the digestive tract or an effect on metabolism. 
Future research on the effect of supplementing diets for weanling pigs with organic acids is needed to improve understanding on their mode of action. More research is needed on the absorption and transport of organic acids in the intestine and their effect on microbial metabolism as well as secretions into the gastrointestinal tract. Further investigation on the effect of supplementation of organic acids on the $\mathrm{pH}$ in the stomach needs to be carried out. In the aforementioned studies, the lack of a response to organic acid supplementation may have been due to the fact that the response may be different under commercial conditions, i.e. a piggery, than under more sanitary or isolated conditions as is usually the case in a metabolic trial. Future research is needed to evaluate the effect of supplementation with organic acids on nutrient digestibility when weanling pigs are fed diets which have a relatively low essential AA or mineral content. In these situations, organic acid supplementation may be very effective.

\section{REFERENCES}

Bolduan V.G., Jung H., Schneider R., Block J., Klenke B., 1988. Die Wirkung von Propion-und Ameisensäure in der Ferkelaufzucht. J. Anim. Physiol. Anim. Nutr. 59, 72-78

Broz J., Schulze J., 1987. Efficacy of citric acid as a feed additive in early weaned piglets. J. Anim. Physiol. Anim. Nutr. 58, 215-223

Bugaut M., 1987. Occurance, absorption and metabolism of short chain fatty acids in the digestive tract of mammals. Comp. Biochem. Physiol. 86B, 439-472

Burnell T.W., Cromwell G.L., Stahly T.S., 1988. Effects of dried whey and copper sulfate on the growth responses to organic acid in diets for weanling pigs. J. Anim. Sci. 66, 1100-1108

Conway P., 1989. Lactobacilli: fact and fiction. In: R. Grubb, T. Midtvedt, E. Norin (Editors). The Regulatory and Protective Role of the Normal Microflora. Proceedings of the 5th Bengt

E. Gustafsson Symposium. The Macmillan Press Ltd., London, pp. 263-281

Easter R.A., 1988. Acidification of diets for pigs. In: W. Haresign, D.J.A. Cole (Editors). Recent Advances in Animal Nutrition. Butterworths, London, pp. 61-71

Eckel B., Kirchgessner M., Roth F.X., 1992. Zum Einfluß von Ameisensäure auf tägliche Zunahmen, Futteraufnahme, Futterverwertung und Verdaulichkeit. 1. Mitteilung. Untersuchungen zur nutritiven Wirksamkeit von Organischen Säuren in der Ferkelaufzucht. J. Anim. Physiol. Anim. Nutr. 67, 93-100

Edmonds M.S., Izquierdo O.A., Baker D.H., 1985. Feed additive studies with newly weaned pigs: efficacy of supplemental copper, antibiotics and organic acids. J. Anim. Sci. 60, 462-469

Eidelsburger U., Roth F.X., Kirchgessner M., 1992a. Zum Einfluß von Ameisensäuer, Calciumformiat und Natriumhydrogencarbonat auf tägliche Zunahmen, Futteraufnahme, Futterverwertung und Verdaulichkeit. 7. Mitteilung. Untersuchungen zur nutritiven Wirksamkeit von Organischen Säuren in der Ferkelaufzucht. J. Anim. Physiol. Anim. Nutr. 67, 258-267

Eidelsburger U., Kirchgessner M., Roth F.X., 1992b. Zum Einfluß von Fumarsäuer, Salzsäuer, Natriumformiat, Tylosin und Toyocerin auf tägliche Zunahmen, Futteraufnahme, Futterver- 
wertung und Verdaulichkeit. 11. Mitteilung. Untersuchungen zur nutritiven Wirksamkeit von organischen Säuren in der Ferkelaufzucht. J. Anim. Physiol. Anim. Nutr. 68, 82-92

Eidelsburger U., Kirchgessner M., Roth F.X., 1992c. Einfluß von Fumarsäuer, Salzsäuer, Natriumformiat, Tylosin und Toyocerin auf den Säure-Basen-Haushalt. 13. Mittcilung. Untersuchungen zur nutritiven Wirksamkeit von organischen Säuren in der Ferkelaufzucht. J. Anim. Physiol. Anim. Nutr. 68, 165-173

Falkowski J.F., Aherne F.X., 1984. Fumaric and citric acid as feed additives in starter pig nutrition. J. Anim. Sci. 58, 935-938

Gabert V.M. 1994. The effect of supplementation of organic acids, oligosaccharides and lactitol on the digestibility of amino acids and bacterial populations and metabolites in the digestive tract of early-weaned pigs. M.Sc. Thesis. University of Alberta, Edmonton, Canada.

Gedek B., Roth F.X., Kirchgessner M., Wiehler S., Bott A., Eiedelsburger U., 1992. Zum Einfluß von Fumarsäure, Salzsäure, Natriumformiat, Tylosin und Toyocerin auf die Keimzahlen der Mikroflora und deren Zusammensetzung in verschiedenen Segmenten des Gastrointestinaltraktes. 14. Mitteilung. Untersuchungen zur nutritiven Wirksamkeit von organischen Säuren in der Fcrkelaufzucht. J. Anim. Physiol. Anim. Nutr. 68, 209-217

Giesting D.W., Eastcr R.A., 1985. Response of starter pigs to supplementation of corn-soybean meal diets with organic acids. J. Anim. Sci. 60, 1288-1294

Giesting D.W., Easter R.A., 1991. Effect of protein source and fumaric acid supplementation on apparent ileal digestibility of nutrients by young pigs. J. Anim. Sci. 69, 2497-2503.

Giesting D.W., Roos M.A., Easter R.A., 1991. Evaluation of the effect of fumaric acid and sodium bicarbonate addition on performance of starter pigs fed diets of different types. J. Anim. Sci. 69, 2489-2496

Grassmann E., Kirchgessner M., 1979. Zur Wirkung von Citronensäure im Stoffwechsel. Tierphysiol., Tieremähr., Futtermittelk. 42, 152-155

Grassmann E., Klasna T., 1986. Vergleichende Untersuchungen zur Wirkung von Fumar- und Citronensäurezulagen auf Körperzusammensetzung und Enzymaktivitäten unterschiedlich mit Protein versorgter Ratten. Landwirtsch. Forschung 39, 307-319

Grassmann E., Roth F.X., Kirchgessner M., 1992. Intermediär Effekte durch Einsatz on Ameisensäure. 6. Mitteilung. Untersuchungen zur nutritiven Wirksamkeit von organischen Säuren in der Ferkelaufzucht. J. Anim. Physiol. Anim. Nutr. 67, 250-257

Imoto S., Namioka S., 1983. Nutritive value of acetate in growing pigs. J. Anim. Sci. 56, 858-866

Kidder D.E., Manners M.J., 1978. Digestion in the Pig. University of Bristol, Bristol, UK. pp. $69-71,83$

Kirchgessner M., Roth F.X., 1980. Verdaulichkeit und Bilanz von Protein, Energie und einigen Mineralstoffen bci Fumarsäurezulagen an Ferkel. Z. Tierphysiol., Tierernähr., Futtermittelk. 44, 239-246

Kirchgessner M., Roth F.X., 1982a. Fumaric acid as a feed additive in pig nutrition. Pig News Inf. 3, 259-264

Kirchgessner M., Roth F.X., 1982b. Propionsäure als Futteradditiv in der Ferkelaufzucht und Scheinemast. Wirtschaftseig. Futter 28, 225-234

Kirchgessner M., Roth F.X., 1987a. Use of formates in the feeding of piglets. 1st communication: calcium formate. Landwirtsch. Forschung 40, 141-152

Kirchgessner M., Roth F.X., 1987b. Einsatz von Formatiaten in der Ferkelfütterung 2. Mitteilung: Natriumformiat. Landwirtsch. Forschung 40, 287-294

Kirchgessner M., Roth F.X., 1988. Ergotrope Effekte durch Organische Säuren in der Ferkelaufzucht und Schweinemast. Übers. Tierernähr. 16, 93-108

Kirchgessner M., Roth F.X., 1990. Nutritive effect from calcium formate in combination with free acids in the feeding of piglets. Agrobiol. Res. 43, 53-64 
Kirchgessner M., Roth F.X., Tschierschwitz A., Grassmann E., 1982. Nutritiver Effect von Fumarsäure auf Wachstum und Körperzusammensetzung von Ratten. Z. Tierphysiol., Tierernähr., Futtermittelk. 47, 175-186

Luckey T.D., 1984. Perspectives in intestinal ecology. Microccol. Ther. 14, 243-249

Manners M.J., 1970. Milk replacers for piglets. J. Sci. Food Agric. 21, 333-340

Mathew A.G., Sutton A.L., Scheidt A.B., Forsyth D.M. Patterson J.A., Kelly D.T., 1991. Effects of a propionic acid containing feed additive on performance and intestinal microbial fermentation of the weanling pig. In: M.W.A. Verstegen, J. Huisman, L.A. den Hartog (Editors), Proceedings of the 5th International Symposium on Digestive Physiology in Pigs. Wageningen (Doorwerth), Netherlands, pp. 464-469

Mosenthin R., Sauer W.C., Ahrens F., de Lange C.F.M., Bornholdt U., 1992. Effect of dietary supplements of propionic acid, siliceous earth or a combination of these on the energy, protein and amino acid digestibilities and concentrations of microbial metabolites in the digestive tract of growing pigs. Anim. Feed Sci. Technol. 37, 245-255

Muralidhara K.S., Sheggeby G.G., Elliker P.R., England D.C., Sandine W.E., 1977. Effect of feeding Lactobacilli on the coliform and Lactobacillus flora of intestinal tissue and feces from piglets. $\mathbf{J}$. Food Prot. 40, 288-296

Pallauf J., Götterr W., Krämer K., 1987. Zum Einfluß von Fumarsäure auf Nährstoffverdaulichkeit und N-Bilanz beim Ferkel. Lanwirtsch. Forschung 40, 120-130

Porter P., Kenworthy R., 1969. A study of intestinal and urinary amines in pigs in relation to weaning. Res. Vet. Sci. 10, 440-447

Radecki S.V., Juhl M.R., Miller E.R., 1988. Fumaric and citric acids as feed additives in starter pig diets: effect on performance and nutrient balance. J. Anim. Sci. 66, 2598-2605

Ravindran V., Kornegay E.T., 1993. Acidification of weaner pig diets: a revicw. J. Sci. Food Agric. 62, 313-322

Risley C.R., Kornegay E.T., Lindemann M.D., Weakland S.M., 1991. Effects of organic acids with and without a microbial culture on performance and gastrointestinal tract measurcments of weanling pigs. Anim. Feed Sci. Technol. 35, 259-270

Risley C.R., Kornegay E.T., Lindemann M.D., Wood C.M., Eigel W.N., 1992. Effect of feeding organic acids on selected intestinal content measurements at varying times postweaning in pigs. J. Anim. Sci. 70, 196-206

Roth F.X., Kirchgessner M., 1988. Zum Einsat7. von Essigsäure in der Ferkelfütterung. Lanwirtsch. Forschung 41, 253-258

Roth F.X., Kirchgessner M., Eidelsburger U., 1992. Zum Einfluß von Ameisensäure auf pH-Wert, Trokenmassgehalt, Konzentrationen an flüchtigen Fettsäuren und Milchäsure im Gastrointestinaltract. J. Anim. Physiol. Anim. Nutr. 67, 148-156

Sauer W.C., Ozimek L., 1986. Digestibility of amino acids in swine: results and their practical applications. A review. Livest. Prod. Sci. 15, 367-388

Savage D.C., 1977. Microbial ecology of the gastrointestinal tract. Ann. Rev. Microbiol. 31, 107-133

Sutton A.L., Mathew A.G., Scheidt A.B., Patterson J.A., Kelly D.T., 1991. Effects of carbohydrate sources and organic acids on intestinal microflora and performance of the weanling pig. In: M.W.A. Verstegen, J. Huisman, L.A. den Hartog (Editors). Proceedings of the 5th International Symposium on Digestive Physiology in Pigs. Wageningen (Doorwerth), Netherlands, pp. $442-427$

Tschierschwitz V.A., Grassmann E., Kirchgessner M., Roth F.X., 1982. Zur Wirkung von Fumarsäurezulagen auf Aktivitäten von Leberenzymen (GOT, GPT, SUCCDH) bei unterschiedlicher Energie- und Proteinversorgung wachsender Ratten. Z. Tierphysiol., Tiercrnähr., Futtermittelk. 48, 253-259

Voet D., Voet J.G., 1990. Biochemistry. John Wiley and Sons, New York 
Wolffram S., Bisang B., Grenacher B., Scharrer E., 1990. Transport of tri- and dicarboxylic acids across the intestinal brush border membrane of calves. J. Nutr. 120, 767-774

Wolffram S., Hagemann C., Grenacher B., Scharrer, E, 1992. Characterization of the transport of tri- and dicarboxylates by pig intestinal brush-border membrane vesicles. Comp. Biochem. Physiol. 101A, 759-767

Zhang J., Pettigrew J.E., Chester-Jones H., Cornelius S.G., Moser R.L., 1986. Efficacy of sodium diacetate as a growth promotant for swine. Nutr. Rep. Int. 33, 893-898

\section{STRESZCZENIE}

Efekty uzupelniania dawek pokarmowych dla odsadzonych prosiąt kwasami organicznymi - przegląd literatury

Stwierdzono, że uzupetnienie dawek pokarmowych dla odsadzonych prosiąt kwasami organicznymi (np. cytrynowym, mrówkowym i propionowym) wplywa w wiclu przypadkach na zwiększenie średnich dziennych przyrostów (ADG, od 4 do $27 \%$ ) oraz na wykorzystanic paszy na przyrost (G/F, od 3 do $15 \%$ ), a także na zmniejszenie przypadków występowanił biegunek. Dodatek kwasów organicznych jednakże nie zawsze poprawia ADG i G/F. W przeglądzie szeroko dyskutuje się potencjalne przyczyny uzyskania rozbieżnych wyników. Wplyw kwasów organicznych na zwiçkszenie przyrostów może być przypisany zwiększonej retencji składników pokarmowych i energii oraz strawności (do 4\%), zmianom populacji bakteryjnej i metabolitów w przewodzie pokarmowym oraz/lub wpływowi na przemiany skladników pokarmowych. Istnieje potrzeba dalszych badań nad fizjologicznymi, mikrobiologicznymi i biochemicznymi mechanizmami działania kwasów organicznych dodawanych do dawek dla odsadzonych prosiąt. 